\title{
Movement patterns of juvenile Atlantic tarpon (Megalops atlanticus) in Brewers Bay, St. Thomas, U.S. Virgin Islands
}

\author{
Mareike D. Duffing Romero ${ }^{1 *}$ (D), Jordan K. Matley ${ }^{1,2}$, Jiangang Luo ${ }^{3}$, Jerald S. Ault ${ }^{3}$, Simon J. Pittman ${ }^{4}$ and \\ Richard S. Nemeth ${ }^{1}$
}

\begin{abstract}
Background: Atlantic tarpon (Megalops atlanticus) are a highly migratory species ranging along continental and insular coastlines of the Atlantic Ocean. Due to their importance to regional recreational and sport fisheries, research has been focused on large-scale movement patterns of reproductively active adults in areas where they are of high economic value. As a consequence, geographically restricted focus on adults has left significant gaps in our understanding of tarpon biology and their movements, especially for juveniles in remote locations where they are common. Our study focused on small-scale patterns of movement and habitat use of juvenile tarpon using acoustic telemetry in a small bay in St. Thomas, US Virgin Islands.

Results: Four juvenile tarpon (80-95 cm FL) were tracked from September 2015 to February 2018, while an additional eight juveniles (61-94 cm FL) left the study area within 2 days after tagging and were not included in analysis. Four tarpon had $>78 \%$ residency and average activity space of $0.76 \mathrm{~km}^{2}$ (range $0.08-1.17 \mathrm{~km}^{2}$ ) within Brewers Bay $(1.8$ $\mathrm{km}^{2}$ ). Their vertical distribution was $<18 \mathrm{~m}$ depth with occasional movements to deeper water. Activity was greater during day compared to night, with peaks during crepuscular periods. During the day tarpon used different parts of the bay with consistent overlap around the St. Thomas airport runway and at night tarpon typically remained in a small shallow lagoon. However, when temperatures in the lagoon exceeded $30^{\circ} \mathrm{C}$, tarpon moved to cooler, deeper waters outside the lagoon.
\end{abstract}

Conclusion: Our results, although limited to only four individuals, provide new baseline data on the movement ecology of juvenile Atlantic tarpon. We showed that juvenile tarpon had high residency within a small bay and relatively stable non-overlapping daytime home ranges, except when seasonally abundant food sources were present. Finescale acoustic tracking showed the effects of environmental conditions (i.e., elevated seawater temperature) on tarpon movement and habitat use. These observations highlight the need for more extensive studies of juvenile tarpon across a broader range of their distribution, and compare the similarities and differences in behavior among various size classes of individuals from small juveniles to reproductively mature adults.

Keywords: Acoustic telemetry, Home range, Vertical movement, Diel movement, Environmental effects

*Correspondence: marapp15@gmail.com

${ }^{1}$ Center for Marine and Environmental Studies, University of the Virgin Islands, 2 John Brewers, US Virgin Islands, St. Thomas 00803, USA

Full list of author information is available at the end of the article

\section{Background}

Tracking the movements and migrations of animals in the aquatic environment provides insight into spatial and temporal patterns of habitat use, trophic interactions, reproductive behavior, and behavioral responses to environmental change [1-7]. Recent studies have shown that some highly 
migratory species can exhibit high site fidelity to discrete nearshore areas between migratory events, whereas relatively site-attached species can undergo repeated large-scale migrations for reproduction [1, 8-10]. Integrating these variable patterns of large-scale movements and small-scale activity spaces are becoming increasingly important for implementing ecosystem-based fisheries management, understanding connectivity, and designing ecologically relevant marine managed areas $[5,11,12]$.

Atlantic tarpon (Megalops atlanticus) is a highly mobile pelagic species that supports important recreational and sport fisheries. Tarpon range across coastal areas, estuaries, and rivers of the western and eastern Atlantic Ocean, the Caribbean Islands, and the Gulf of Mexico [6, 13, 14]. Tarpon spend their larval stage as leptocephali in open ocean, and as juveniles settle nearshore in tropical and subtropical estuarine, mangrove and lagoon habitats, where food resources are high and predator pressures are low [15-18]. Adult tarpon range in size from $90-250 \mathrm{~cm}$ fork length (FL) and males reach sexual maturity at about $90 \mathrm{~cm}$ while females at $128 \mathrm{~cm}$ FL [13, 19-21]. Much of our knowledge of tarpon movements and behaviors come from satellite tracking and conventional anchor tag studies conducted in Florida, southeast Atlantic, Gulf of Mexico, and the northwestern Caribbean (e.g., Mexico, Belize, Cuba) $[6,7,13,14$, $22,23]$. These studies have focused on large-scale movements $(>500 \mathrm{~km})$ of large adult tarpon $(>130 \mathrm{~cm} \mathrm{FL})$ that support a valuable sport fishery. The focus on adult tarpon over a limited geographic range leaves large gaps in our understanding of tarpon biology and movement ecology, especially in insular areas throughout the eastern Caribbean where they are common [13]. We applied acoustic telemetry to quantify activity space, rates of movement, vertical distribution and habitat use of juvenile tarpon across diel and seasonal time scales. Additionally, we examined how environmental conditions (i.e., water temperature, dissolved oxygen) influenced their behavior.

\section{Materials and methods Study site}

Brewers Bay is located on the western end of St. Thomas, U.S. Virgin Islands $\left(18^{\circ} 20^{\prime} 28^{\prime \prime} \mathrm{N}, 64^{\circ} 58^{\prime} 40^{\prime \prime} \mathrm{W}\right)$ and is bounded by a commercial airport runway and small lagoon on the south, a sandy beach on the north-eastern shore, and a rocky headland and smaller bay (Perseverance Bay) to the northwest (Fig. 1). Brewers Bay is $1.8 \mathrm{~km}^{2}$ in area, ranges in depth between 0 and $33.1 \mathrm{~m}$ (Fig. 1), and has steep vertical slopes along the airport runway and around the rocky headland. The bay is composed of a variety of habitat types including sand, seagrass, patch reefs, fringing coral reefs, rocky reefs, and rubble and reinforced concrete blocks (dolosse) around the seaward slopes of the airport runway. The lagoon is mostly soft muddy bottom with scattered rocks and dead corals. It is partly enclosed by the airport runway with the remaining shoreline composed of rocky reef or soft sediments, and red mangroves (Rhizophora mangle).

\section{Acoustic array}

The acoustic monitoring system consisted of 45 omnidirectional receivers (VR2W, $69 \mathrm{kHz}$, Innovasea Systems Inc. (previously Vemco), Halifax, Nova Scotia, Canada) that were moored, and spaced equally across Brewers Bay, including eastern Perseverance Bay, and along the southern side of the airport runway (Fig. 1). Range testing of receivers [24] across the study site was conducted over four days in June 2015, by placing receivers in depths ranging from 5 to $19 \mathrm{~m}$ over different substrate types including shallow and deep coral/rock and seagrass/sand [25]. Probabilities of transmission were tested using three A69-1601 InnovaSea transmitters V9-2H (151 dB), V13-1H (153 dB) and V16-4H $(158 \mathrm{~dB})$ that transmitted every $60 \mathrm{~s}$. Transmitters were attached to mooring lines, connected to cinder blocks, and suspended $1 \mathrm{~m}$ above the bottom. A detection probability of $70 \%$ for $\mathrm{V} 13-1 \mathrm{H}$ transmitters was selected providing high coverage throughout the study area with estimated detection ranges of $101 \mathrm{~m}$ in seagrass/sand and $120 \mathrm{~m}$ in coral/rock substrates (Fig. 1). Seawater temperature and dissolved oxygen (DO) were collected at several stations in Brewers Bay using Hobo temperature loggers (Onset Computer Corporation, Bourne, MA, USA) and miniDot DO loggers (Precision Measurement Engineering Inc, Vista, CA, USA) that were attached to acoustic receiver moorings. Temperature loggers were deployed in August 2015, DO loggers were deployed in February 2016, and both recorded data at 15-min intervals (Fig. 1).

\section{Fish capture}

All capture and tagging methodology in Brewers Bay was approved by the University of the Virgin Islands Institutional Animal Care and Use Committee (IRB \#7478071). Juvenile Atlantic tarpon were caught using hook and line from a boat or dock between September 2015 and November 2016. As each fish was reeled in, it was guided alongside the boat or dock and into a floating cradle constructed of PVC pipe, plastic mesh, and foam noodles for buoyancy. Once in the cradle, the fish was held under water, turned upside-down to induce tonic-immobility, and the hook was removed from the mouth. Each fish $(n=14)$ was measured for fork length (FL) and total length (TL) to the nearest millimeter $(\mathrm{mm})$. Acoustic transmitters (either V13 [13 $\mathrm{mm} \times 36 \mathrm{~mm} ; n=8]$ or V13P [13 $\mathrm{mm} \times 46 \mathrm{~mm} ; n=6$; pressure tags that provide depth data], $69 \mathrm{kHz}$, Innovasea Inc, Halifax, NS, Canada) were surgically implanted into the body cavity on the ventral side of the fish [26]. The incision was closed with surgical 


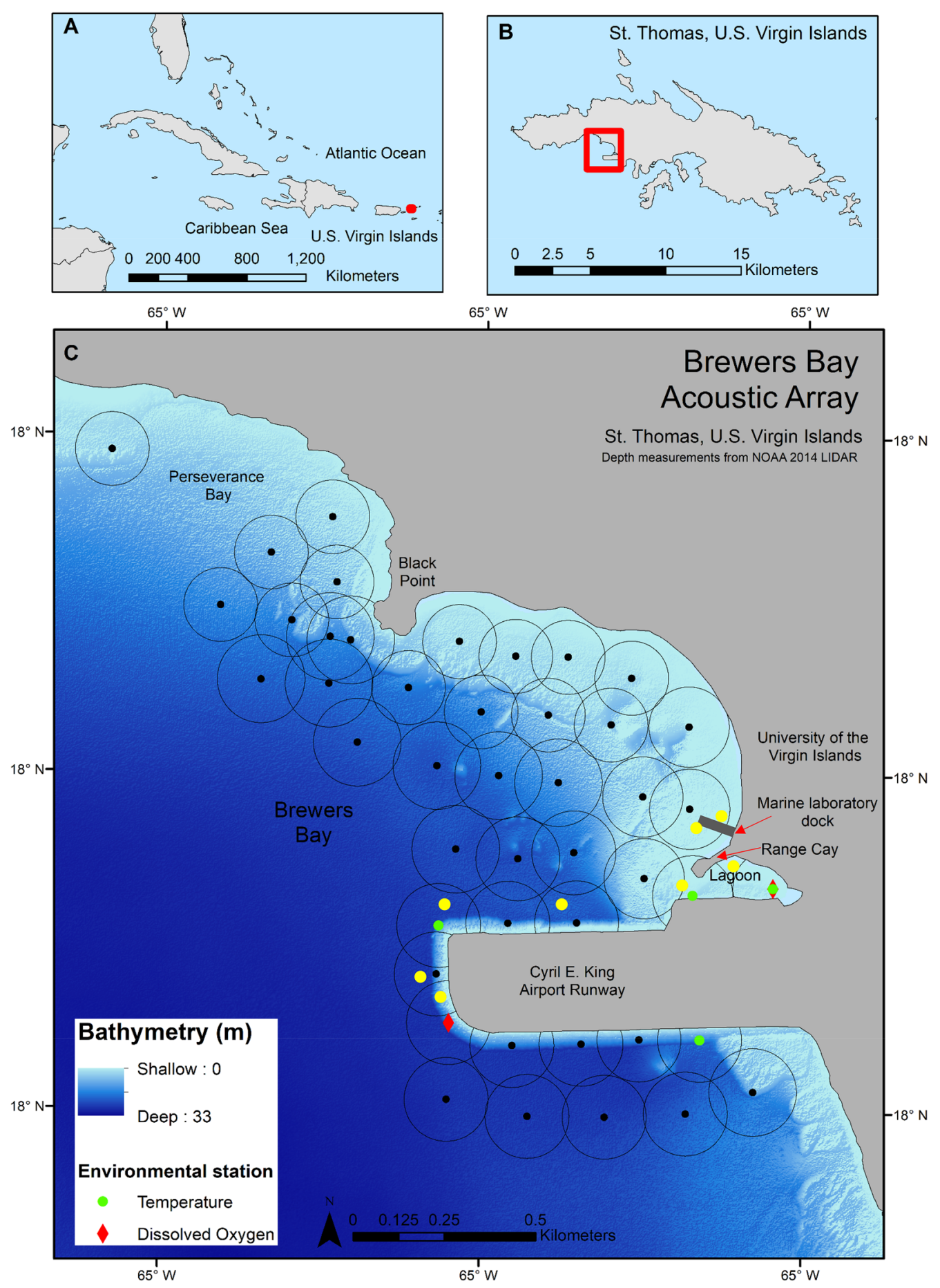

Fig. 1 Map of the Caribbean (a) and the island of St. Thomas in the US Virgin Islands (b) and study site in Brewers Bay (c) depicting bathymetry and the acoustic array with station number and approximate range of $70 \%$ detection probability (circles). Detection ranges varied by habitat (deep hard bottom $=115 \mathrm{~m}$, deep soft bottom $=120 \mathrm{~m}$, shallow soft and hard bottom $=101 \mathrm{~m}$ ) based on range testing. Location of environmental data logger stations shown as green dots (temperature) and red diamonds (dissolved oxygen). Yellow dots represent approximate location where juvenile Atlantic tarpon were tagged and released. 
staples and treated with antibacterial ointment (note: antibacterial ointment is no longer used on incision and sutures). Fish remained immersed in open seawater the entire time so no general or local anesthetic was administered, which allowed for the release of fish shortly after tagging and data collection were completed. Fish were turned back over, the head was faced into the current to increase ventilation, and after a few minutes of recovery, fish were released at the capture location (Fig. 1).

\section{Data processing}

Detections were downloaded from receivers every 3 months and analyzed using R Version 3.4.3 [27]. For each tarpon $(n=14)$ the total number of detections, first/last day detected, number of days between first and last day, and total days detected were calculated. Detections for each individual tarpon by receiver were plotted through time to investigate the presence of dropped tags, dead individuals, and short-term residency. Of the 14 juvenile tarpon that were tagged, four $(n=4)$ individuals had at least 1 month of tracking data to conduct spatial home range analysis. Three of these tarpon were detected for 344-472 days and also had pressure transmitters, thus were used to analyze monthly and seasonal trends in rates of movement, activity space, and vertical distribution (Table 1). Of the remaining ten tarpon that were excluded from analysis, eight $(n=8)$ were within the array two days or less and had insufficient detections for analyses, and two $(n=2)$ had either died or shed their tags (Table 1).
Temporal data were examined for seasonal and diel patterns. Seasons were defined as spring (March, April, May), summer (June, July, August), fall (September, October, November) and winter (December, January, February). Crepuscular periods were calculated using astronomical twilight based on daily sunrise/sunset time charts for Charlotte Amalie, St. Thomas, U. S. Virgin Islands [28]. Specifically, dawn was defined as $-1 \mathrm{~h}$ before astronomical morning and $+1 \mathrm{~h}$ after sunrise to account for seasonal changes in day length. Likewise, dusk was defined as $-1 \mathrm{~h}$ before astronomical twilight to $+1 \mathrm{~h}$ after sunset. Day and night periods were the remaining hours between bracketed dawn and dusk, respectively.

\section{Data analysis and statistics}

Residency index was calculated for the four fish used in analyses by dividing total days each fish was detected within the Brewers Bay array by number of days between the first and last detection. Residency Index was defined as the percentage of days spent within Brewers Bay array for the duration of time that each fish was tracked.

Center of activity (COA) for juvenile tarpon $(n=4)$ was calculated every 30 min using mean position (latitude and longitude) of all detections during that time step [29]. Distance between COA relocation points and difference in time between each relocation point were calculated for each fish using 'adehabitatLT' package of $\mathrm{R}$ environment [30]. COA values were used to calculate rate of

Table 1 Summary data for Atlantic tarpon (M. atlanticus) caught and tracked in Brewers Bay acoustic array, including date caught $(\mathrm{mm} / \mathrm{dd} / \mathrm{yyyyy})$, total length ( $T L)$, fork length (FL), total number of detections and total residency time detected in Brewers Bay

\begin{tabular}{|c|c|c|c|c|c|c|c|c|c|}
\hline Fish ID & Tag date & $\mathrm{TL}(\mathrm{cm})$ & $\mathrm{FL}(\mathrm{cm})$ & $\begin{array}{l}\text { Total } \\
\text { detections }\end{array}$ & $\begin{array}{l}\text { First day } \\
\text { detected }\end{array}$ & $\begin{array}{l}\text { Last day } \\
\text { detected }\end{array}$ & $\begin{array}{l}\text { Days between } \\
\text { first and last } \\
\text { detection }\end{array}$ & $\begin{array}{l}\text { Total days } \\
\text { detected }\end{array}$ & $\begin{array}{l}\text { Residency } \\
\text { index (\%) }\end{array}$ \\
\hline $36032^{a}$ & $9 / 17 / 2015$ & 109 & 95 & 12231 & 9/17/2015 & 10/19/2015 & 32 & 28 & 88 \\
\hline $10980 \mathrm{P}^{\mathrm{a}}$ & $6 / 17 / 2016$ & 96 & 80 & 54564 & $6 / 18 / 2016$ & $5 / 28 / 2017$ & 344 & 330 & 96 \\
\hline $10979 \mathrm{p}^{\mathrm{a}}$ & $6 / 26 / 2016$ & 112 & 95 & 106564 & $6 / 26 / 2016$ & $7 / 1 / 2017$ & 370 & 287 & 78 \\
\hline $2966 P^{a}$ & $10 / 25 / 2016$ & 96 & 85 & 395606 & 10/26/2016 & $2 / 10 / 2018$ & 472 & 464 & 99 \\
\hline $36034^{c}$ & $10 / 16 / 2015$ & 90 & 78 & 326110 & $10 / 16 / 2015$ & 7/11/2016 & 269 & 271 & $\mathrm{n} / \mathrm{a}$ \\
\hline $36036^{c}$ & $10 / 21 / 2015$ & 130 & 91.2 & 2017 & $10 / 22 / 2015$ & $1 / 25 / 2016$ & 95 & 74 & $\mathrm{n} / \mathrm{a}$ \\
\hline $59272^{b}$ & 1/12/2016 & 86.4 & 76.1 & 10 & $1 / 12 / 2016$ & 1/13/2016 & 1 & 1 & $\mathrm{n} / \mathrm{a}$ \\
\hline $36044^{b}$ & $5 / 24 / 2016$ & 70 & 61 & 5 & $5 / 24 / 2016$ & $5 / 24 / 2016$ & 1 & 1 & $\mathrm{n} / \mathrm{a}$ \\
\hline $36045^{b}$ & $6 / 1 / 2016$ & 130 & 91.2 & 14 & $6 / 1 / 2016$ & $6 / 1 / 2016$ & 1 & 1 & $\mathrm{n} / \mathrm{a}$ \\
\hline $2965 \mathrm{P}^{b}$ & 8/8/2016 & 96 & 85 & 70 & 8/9/2016 & 8/9/2016 & 1 & 1 & $\mathrm{n} / \mathrm{a}$ \\
\hline $2964 \mathrm{P}^{\mathrm{b}}$ & 8/14/2016 & 100 & 80 & 11 & $8 / 14 / 2016$ & $8 / 14 / 2016$ & 1 & 1 & $\mathrm{n} / \mathrm{a}$ \\
\hline $36039^{b}$ & 8/16/2016 & 100 & 94 & 10 & $8 / 16 / 2016$ & 8/16/2016 & 1 & 1 & $\mathrm{n} / \mathrm{a}$ \\
\hline $2963 P^{b}$ & $9 / 15 / 2016$ & 92 & 77 & 660 & $9 / 16 / 2016$ & $9 / 17 / 2016$ & 2 & 2 & $\mathrm{n} / \mathrm{a}$ \\
\hline $24976^{b}$ & 10/29/2016 & 96 & 83 & 212 & $11 / 8 / 2016$ & $11 / 8 / 2016$ & 1 & 1 & $\mathrm{n} / \mathrm{a}$ \\
\hline
\end{tabular}

$P$ acoustic pressure transmitter measured depth, $n / a$ not applicable

${ }^{a}$ Fish used for Brewers Bay spatial analyses

${ }^{\mathrm{b}}$ Transient fish not used in spatial analyses

' Fish died or shed tag 
movement (ROM) and activity space for individual fish, and included minimum convex polygons (100\% MCP) and kernel utilization distributions (50\% and 95\% KUD).

Activity space, which incorporates MCP, 50\% KUD and 95\% KUD, was calculated using the 'move' and 'adehabitat' package in $\mathrm{R}$ environment [30, 31]. MCPs provided information on the extent of an individual's range or area used and included all outlying points that might be the result of exploratory movement or periodic migration not part of their typical activity. KUDs highlight the density of positions of an individual within the activity space based on COAs (i.e., 50\% KUD = high density, 95\% $\mathrm{KUD}=$ low density), as well as estimated error around these positions [32, 33]. When necessary, a 'land' barrier polygon was used to clip out the area of MCP and KUD polygons that fell on land ('rgeos' package, [34]). The calculated MCP and KUD (50\% and 95\%) activity spaces were plotted in ArcGIS 10.6 for annual, monthly, and diel periods. To calculate the degree of overlap in $50 \%$ and 95\% KUD among individuals over diel and monthly time periods, a home range (HR) percent overlap analyses was applied using the 'kerneloverlaphr' function of the 'adehabitatHR' package [30,35,36]. The HR percent overlap analyses calculates the proportion of animal a's home range that is overlapped by animal b's home range [30, 35, 36]. The data output matrix provides indices of overlap for all pairs of animals $[35,36]$. Using the matrix output, average and ranges in fish overlap values were calculated. Repeated measures analyses of variance (RM-ANOVA) was used to test for differences in KUD across monthly and diel periods. All monthly analyses used data from three $(n=3)$ tarpon that had average KUD activity space representing each month (Table 1). Individual tarpon were treated as random variables, and either monthly or diel periods were treated for autocorrelation effects ('corAR1') using the 'lme' function of the 'nlme' package for $\mathrm{R}[37,38]$. To assess relationship between monthly ROM and 50\% KUD size, a linear regression was applied.

Rate of movement (ROM, $\mathrm{m} / \mathrm{s}$ ) was calculated by dividing the distance between consecutive COA position values by the time difference between these consecutive points. Kruskal-Wallis and Tukey post hoc tests were used to test for differences in ROM between diel periods and a two-way ANOVA was used to test for differences in diel ROM across seasons. ROM provides a useful metric for fish activity during diel periods and can also be used as a proxy for feeding behavior [47].

Vertical distribution was calculated for tarpon tagged with depth-enabled transmitters $(n=3$, Table 1$)$. Depth measurements were binned into hourly and monthly periods and boxplots were applied to elucidate their vertical movement patterns. ANOVA and Tukey post hoc tests were used to test for differences in vertical movement across diel and monthly periods.

Environmental conditions and their relationship to tarpon movement and habitat use were assessed for seawater temperature and DO. Daily average number of detections, average temperature and average DO within the lagoon and waters along the airport runway were analyzed by applying a linear regression for the study period (September 2015-February 2018).

\section{Results}

Fourteen $(n=14)$ juvenile tarpon were captured and acoustically tagged in Brewers Bay (average FL $83.7 \mathrm{~cm}$, range $61-95 \mathrm{~cm}$; Table 1$)$. Only four $(n=4)$ juvenile tarpon provided a sufficient number of detections over a sufficient duration (32-472 days), and a residency index of $78-100 \%$, to be included in our spatial analysis (Table 1$)$. Eight $(n=8)$ fish were detected for less than a week and had fewer than 1000 detections and upon assessment, it was determined that the two remaining fish detected within the bay had died or shed their tags within one day following release.

\section{Activity space}

The activity space of juvenile tarpon varied among individuals and through time. The average MCP for juvenile tarpon $(n=4)$ was $0.97 \mathrm{~km}^{2}$ (range $0.77-1.17 \mathrm{~km}^{2}$ ), while the average $95 \%$ and $50 \%$ KUD was $0.76 \mathrm{~km}^{2}$ (range $0.49-0.99 \mathrm{~km}^{2}$ ) and $0.13 \mathrm{~km}^{2}$ (range $0.08-0.20 \mathrm{~km}^{2}$ ), respectively (Table 2; Fig. 2). Comparison of mean day,

Table 2 Calculated home range size $\left(\mathrm{km}^{2}\right)$ for each tarpon based on 50\% and 95\% Kernel utilization distribution (KUD) and 100\% minimum convex polygon (MCP); number of center of activity (COA) points that fell on land and total percentage of COA points on land removed out of total COA points used for home range analyses

\begin{tabular}{lllllll}
\hline Fish ID & Total COA points & $\begin{array}{l}\text { MCP 100\% area } \\
\left.\mathbf{( k m}^{2}\right)\end{array}$ & $\begin{array}{l}\text { KUD 95\% area } \\
\left.\mathbf{( k m}^{2}\right)\end{array}$ & $\begin{array}{l}\text { KUD 50\% area } \\
\left.\mathbf{( k m}^{2}\right)\end{array}$ & $\begin{array}{l}\text { COA points on } \\
\text { land }\end{array}$ & $\begin{array}{l}\text { Percentage } \\
\text { of COA points } \\
\text { removed }\end{array}$ \\
\hline 2966 & 19,367 & 1.174 & 0.988 & 0.200 & 123 & 0.64 \\
10979 & 11,888 & 1.055 & 0.619 & 0.075 & 163 & 1.37 \\
10980 & 10,425 & 0.864 & 0.492 & 0.090 & 166 & 1.59 \\
36032 & 887 & $0.767^{2}$ & 0.938 & 0.149 & 7 & 0.79 \\
\hline
\end{tabular}

${ }^{\mathrm{a}}$ In this case $100 \%$ MCP is smaller than $95 \%$ KUD based on how they are calculated (see "Materials and methods") 


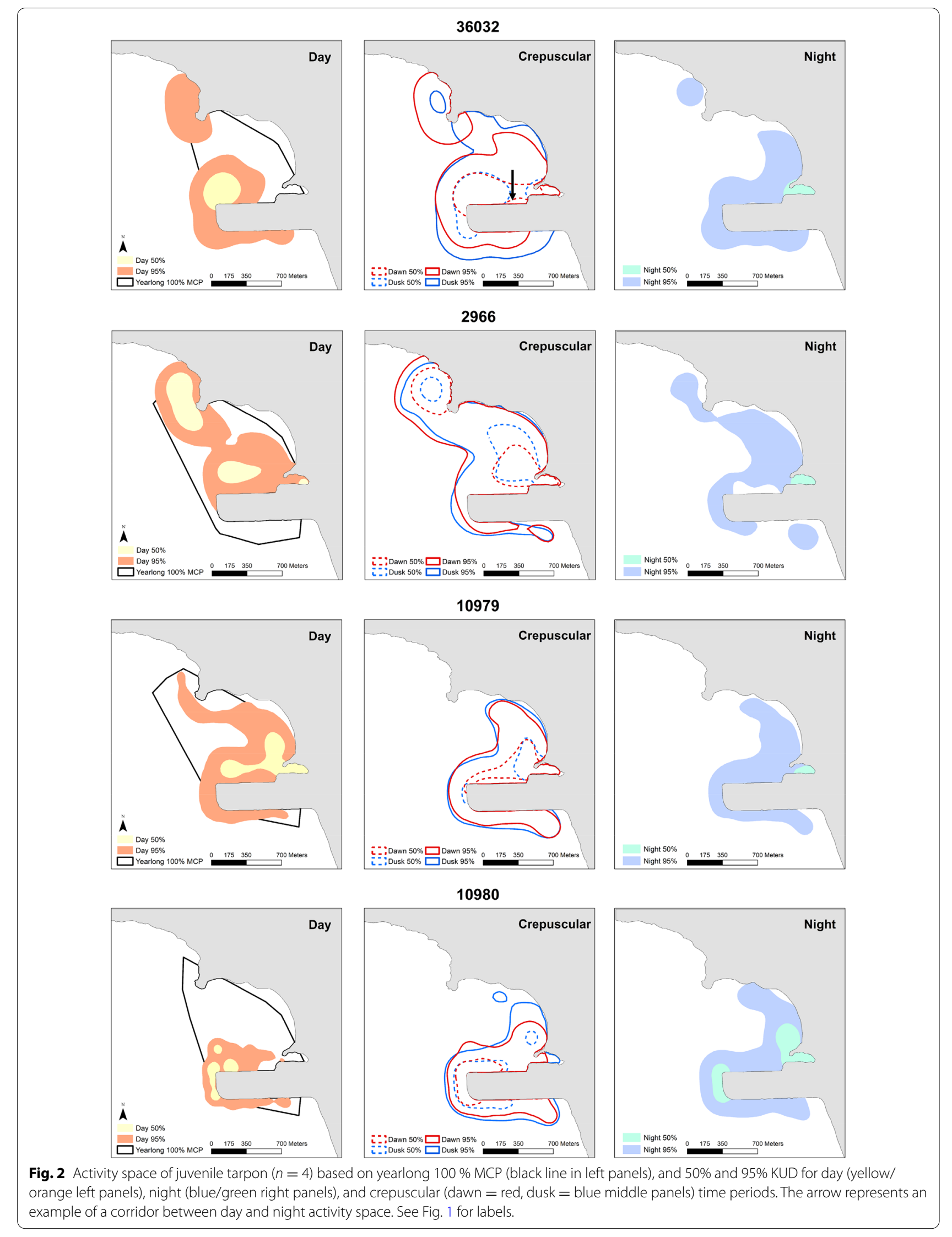


Table 3 Summary of 50\% and 95\% Kernel utilization distribution (KUD) overlap for juvenile tarpon ( $n=3$ ) during day and night for full year, May to March (April excluded) and only April

\begin{tabular}{lllllc}
\hline Month(s) & Diel period & $\begin{array}{l}\text { KUD 50\% area } \pm \text { SE } \\
\left(\mathbf{k m}^{2}\right)\end{array}$ & $\begin{array}{l}\text { KUD 50\% area range } \\
\left(\mathbf{k m}^{2}\right)(\mathbf{\%})\end{array}$ & $\begin{array}{l}\text { KUD 95\% area } \pm \text { SE } \\
\left(\mathbf{k m}^{2}\right)\end{array}$ & $\begin{array}{l}\text { KUD 95\% area } \\
\mathbf{r a n g e}\left(\mathbf{k m}^{2}\right) \\
(\%)\end{array}$ \\
\hline All year & & & $0-27$ & $42 \% \pm 12 \%$ & $11-72$ \\
All year & Day & $12 \% \pm 6 \%$ & $0-99$ & $51 \% \pm 8 \%$ & $28-99$ \\
May-March & Night & $20 \% \pm 18 \%$ & $0-6$ & $23 \% \pm 14 \%$ & $8-55$ \\
May-March & Day & $2 \% \pm 2 \%$ & $0-99$ & $44 \% \pm 10 \%$ & $14-99$ \\
April & Night & $19 \% \pm 18 \%$ & $1-55$ & $63 \% \pm 4 \%$ & $42-74$ \\
April & Day & $20 \% \pm 16 \%$ & $0-32$ & $33 \% \pm 19 \%$ & $11-81$ \\
\hline
\end{tabular}

night and crepuscular activity spaces among juvenile tarpon for both $50 \%$ and $95 \%$ KUDs were not significantly different across diel and crepuscular periods (50\% KUD: $p=0.07$; 95\% KUD: $p=0.44)$ and across months (50\% KUD: $p=0.78$; 95\% KUD: $p=0.29$ ).

Analysis of daytime activity space overlap averaged $12 \%$ for $50 \%$ KUD and $42 \%$ for $95 \%$ KUD during the year (Table 3), with each tarpon showing distinct 50\% KUD core areas centered around northwest corner of runway (ID\#36032), around Black Point and deeper part of Brewers Bay (ID\#2966), in and around the lagoon and Range Cay extending to shallow and deep parts of Brewers Bay (ID\#10979), and around the tip of runway (ID\#10980) (Fig. 2, day). In April, however, overlap for 50\% and 95\% KUD during daytime showed an increase to $20 \%$ and $63 \%$, respectively (Table 3). Excluding the month of April, daytime 50\% and 95\% KUD overlap values declined from 12 to $2 \%$ and $42 \%$ to $23 \%$, respectively (Table 3 ). At nighttime, 50\% KUD areas were centered in shallow Brewers Bay, around the airport runway and particularly inside the shallow lagoon, where juvenile tarpon went at night (Fig. 2, night). Consistent use of these areas at night tended to increase nighttime 50\% and 95\% KUD overlap relative to daytime, except for April, when space overlap decreased at night (Table 3).

\section{Rate of movement}

Average ROM of juvenile tarpon was $0.07 \mathrm{~m} / \mathrm{s}$ $( \pm 0.02 \mathrm{SD})$ and was significantly different among diel periods $(H=12.4, \quad P<0.006)$. Post hoc comparisons between day $($ mean $=0.06 \mathrm{~m} / \mathrm{s} \pm 0.01$ $\mathrm{SD})$ night $($ mean $=0.05 \mathrm{~m} / \mathrm{s} \pm 0.01 \quad \mathrm{SD})$, dawn $\quad($ mean $=0.09 \mathrm{~m} / \mathrm{s} \pm 0.01 \quad \mathrm{SD})$ and dusk (mean $=0.10 \mathrm{~m} / \mathrm{s} \pm 0.01 \mathrm{SD}$ ) showed a significant difference between dusk and nighttime periods only (Tukey HSD: $P<0.01)$. Diel ROM also varied across seasons (2-way ANOVA: $\left.F_{1,15}=253.2, P<0.0001\right)$. Most notable, daytime ROM was significantly lower in winter compared to other seasons (Tukey HSD: $P<0.001$ ). During all seasons, crepuscular ROM peaked between 04:00 to
05:00 and at 18:00 (Fig. 3a). ROM was not significantly different across months (mean $=0.07 \mathrm{~m} / \mathrm{s} \pm 0.01 \mathrm{SD})$, but there was a strong relationship between monthly ROM and $50 \%$ KUD $\left(F=34.07, P=0.0001, R^{2}=0.77\right)$ with the highest rates for both metrics during the months of April, June and September (Fig. 3b).

\section{Vertical movement}

Vertical movement of juvenile tarpon with pressure transmitters $(n=3)$ varied among time of the day (ANOVA: $F_{1,3}=36,526, P<0.0001$ ) (Fig. 4). Tarpon used more of the water column during the day ranging between 2 to $13 \mathrm{~m}$ average depth and 16 to $27 \mathrm{~m}$ maximum depth (Fig. 4). At night, tarpon stayed in shallower waters ranging from 0 to $5 \mathrm{~m}$ average depth and 8 to $14 \mathrm{~m}$ maximum depth (Fig. 4; Additional file 1: Table S1). Nighttime vertical movements were partly constrained when tarpon were in lagoon (maximum depth $4 \mathrm{~m}$, Fig. 2). During dawn and dusk, average depth of tarpon ranged between 0 to $8 \mathrm{~m}$ (Fig. 4; Additional file 1: Table S1). Vertical distribution across months showed no consistent patterns among the three tarpon with depth transmitters.

\section{Movement and environmental variability}

Water temperature in Brewers Bay ranged from $25-28^{\circ} \mathrm{C}$ in winter to $29-32{ }^{\circ} \mathrm{C}$ in late summer and early fall. Inside the lagoon water temperature showed greater fluctuations on a daily basis and had a greater range (mean $=28.3{ }^{\circ} \mathrm{C} \pm 1.27 \mathrm{SD}$, range $=24.8-32.0{ }^{\circ} \mathrm{C}$ ) than in the bay $\left(\right.$ mean $=28.1{ }^{\circ} \mathrm{C} \pm 1.15 \mathrm{SD}$, range $\left.=25.6-30.6{ }^{\circ} \mathrm{C}\right)$ (Fig. 5). Water temperature had a strong effect on tarpon movement and habitat use. We found a significant negative relationship between number of tarpon detections and temperature in the lagoon at night (adjusted $R^{2}=0.0 .32 ; P<0.001$ ), but no relationship between frequency of detections in the lagoon or around the runway at other times of day (Fig. 6). Juvenile tarpon were present in the lagoon at night when temperature ranged between 26 and $28{ }^{\circ} \mathrm{C}$; however, once temperature reached $29{ }^{\circ} \mathrm{C}$ frequency of tarpon detections decreased rapidly and 

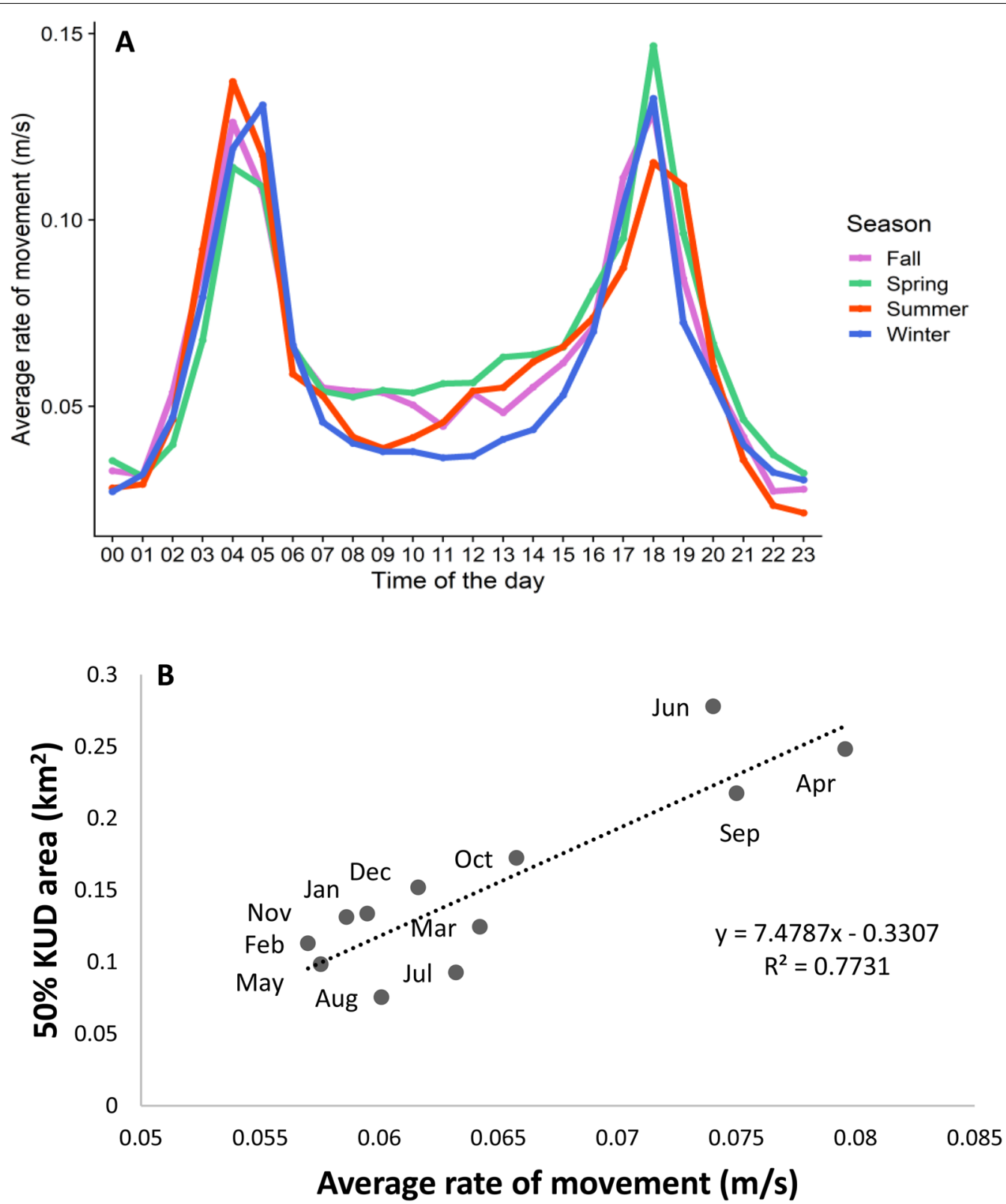

Fig. 3 a Diel ROM of juvenile tarpon by season of the year: Spring (March, April, May), Summer (June, July, August), Fall (September, October, November) and Winter (December, January, February). b Relationship between average ROM and core activity space 50\% KUD for four juvenile tarpon during each month

stopped at about $30.5{ }^{\circ} \mathrm{C}$ (Fig. 6), indicating tarpon left the lagoon. Water temperatures in the lagoon reached or exceeded $30.5^{\circ} \mathrm{C}$ on 59 day of the study period compared to only 4 days at the airport runway. Likewise, water temperatures $26{ }^{\circ} \mathrm{C}$ colder were recorded on 61 day in the lagoon but only on 16 day along runway. At times of high lagoon temperatures, juvenile tarpon left the lagoon and had higher frequency of detections at night along the tip and south side of the airport runway (i.e., stations 248,
249, 285, 251, 282; Fig. 1), where nighttime maximum water temperatures were cooler (Figs. 5, 6a). When water temperatures in lagoon cooled to below $30.5{ }^{\circ} \mathrm{C}$, juvenile tarpon returned to resting in lagoon at night (Fig. 5).

Similar to water temperature, dissolved oxygen concentrations in the lagoon varied widely from 0.9 to $7.1 \mathrm{mg} / \mathrm{L}$ (mean $=4.7 \pm 1.89 \mathrm{SD}$ ), but were more stable along the airport runway (mean $=6.1 \pm 1.9 \mathrm{SD}$, range $5.3-$ $6.6 \mathrm{mg} / \mathrm{L}$ ) (Fig. 5). Based on detection frequencies, there 


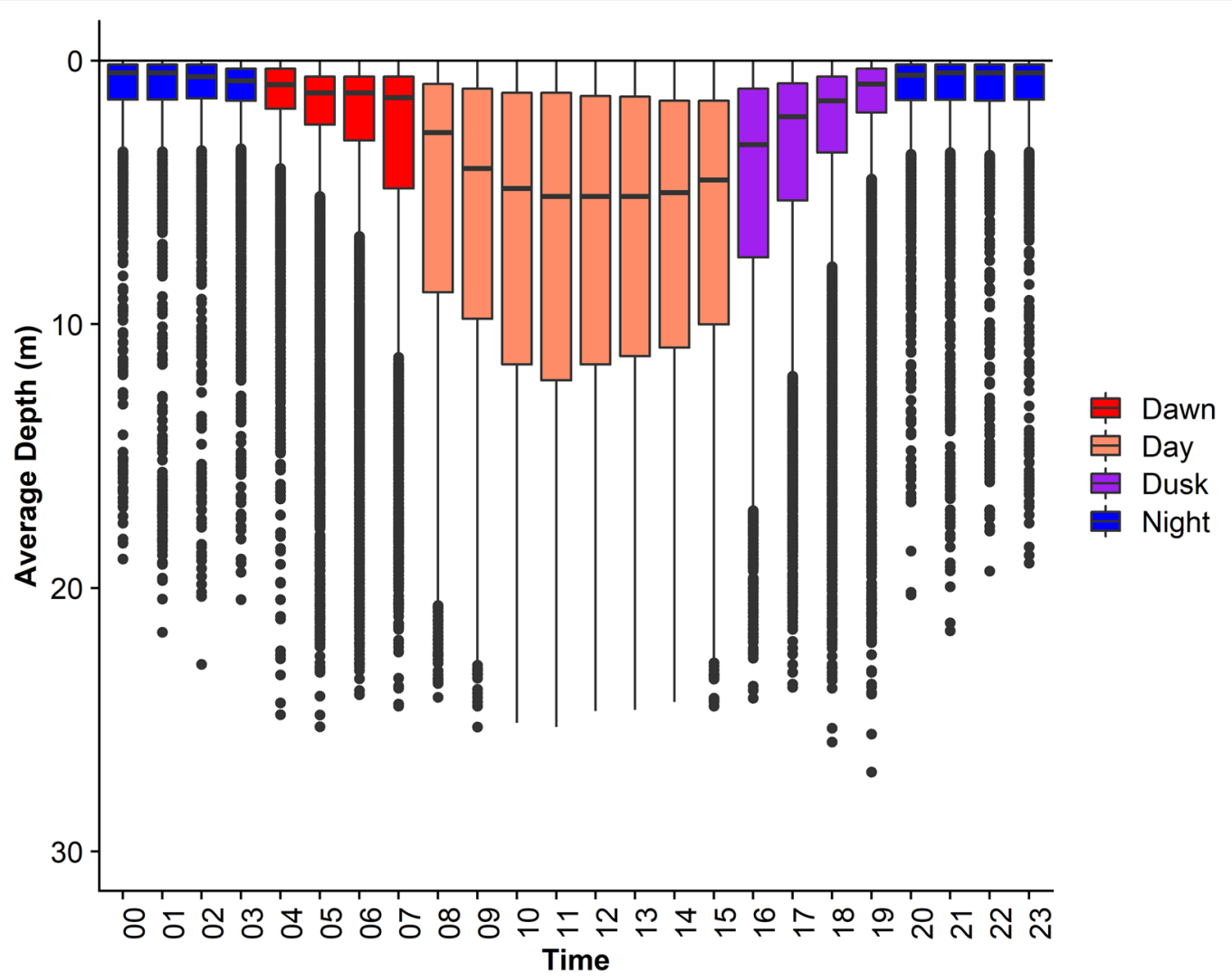

Fig. 4 Boxplot of daily distributions by hour of vertical movement of three juvenile tarpon during diel (day, night) and crepuscular (dawn, dusk) periods

was no significant relationship in number of detections of tarpon at different levels of dissolved oxygen within the lagoon or the runway (Fig. 6b), indicating that tarpon seemed to tolerate the low oxygen levels in the lagoon, especially at night

\section{Discussion}

To our knowledge, this study provided some of the first data on small-scale three-dimensional movement patterns of juvenile Atlantic tarpon $(n=4)$ by way of passive acoustic telemetry. The data can serve as a baseline for juvenile tarpon movement ecology that can further be examined and use for comparison to adult movements or other regions $[6,22]$. Although most juvenile tarpon $(n=8)$ left the bay shortly after tagging and their fate remained unknown, and two fish likely died or shed their tags, the remaining four fish provided useful data on the movement ecology of juvenile tarpon. Juvenile tarpon were resident within the bay $78 \%$ to $99 \%$ of time, but some transient behavior was observed for two of the larger individuals (i.e., both were $95 \mathrm{~cm} \mathrm{FL).} \mathrm{One} \mathrm{tarpon}$ (ID \#10979) left the bay for nearly 2 months (October and November) before returning to its home range for another 7 months. The second tarpon (ID\#3032) remained within Brewers Bay for 1 month before departing mid-October, but it was then detected at an acoustic array $12 \mathrm{~km}$ offshore in January. Interestingly, both tarpon departed in October when water temperature was high. Seasonal movements, such as these, by Atlantic tarpon and other coastal species have been attributed to food availability, reproductive maturity (spawning aggregations) and changes in environmental conditions (i.e., temperature, dissolved oxygen) $[6,13,15,16,39-41]$.

We found that juvenile tarpon had distinct daytime $50 \%$ KUDs, and core areas $\left(0.07-0.20 \mathrm{~km}^{2}\right)$ within Brewers Bay that overlapped very little with the other individuals for most of the year $(<2 \%)$. At night, tarpon tended to move into or near a small, shallow lagoon in Brewers Bay, which resulted in an increase in overlap of $50 \%$ KUDs during most months. The spatial patterns displayed by juvenile tarpon suggest habitat partitioning during daytime and sheltering and protection from predation in a common area at night $[6,13,17$, 18, 42]. During April, however, daytime overlap in 50\% KUD area showed a tenfold increase, as they shifted 


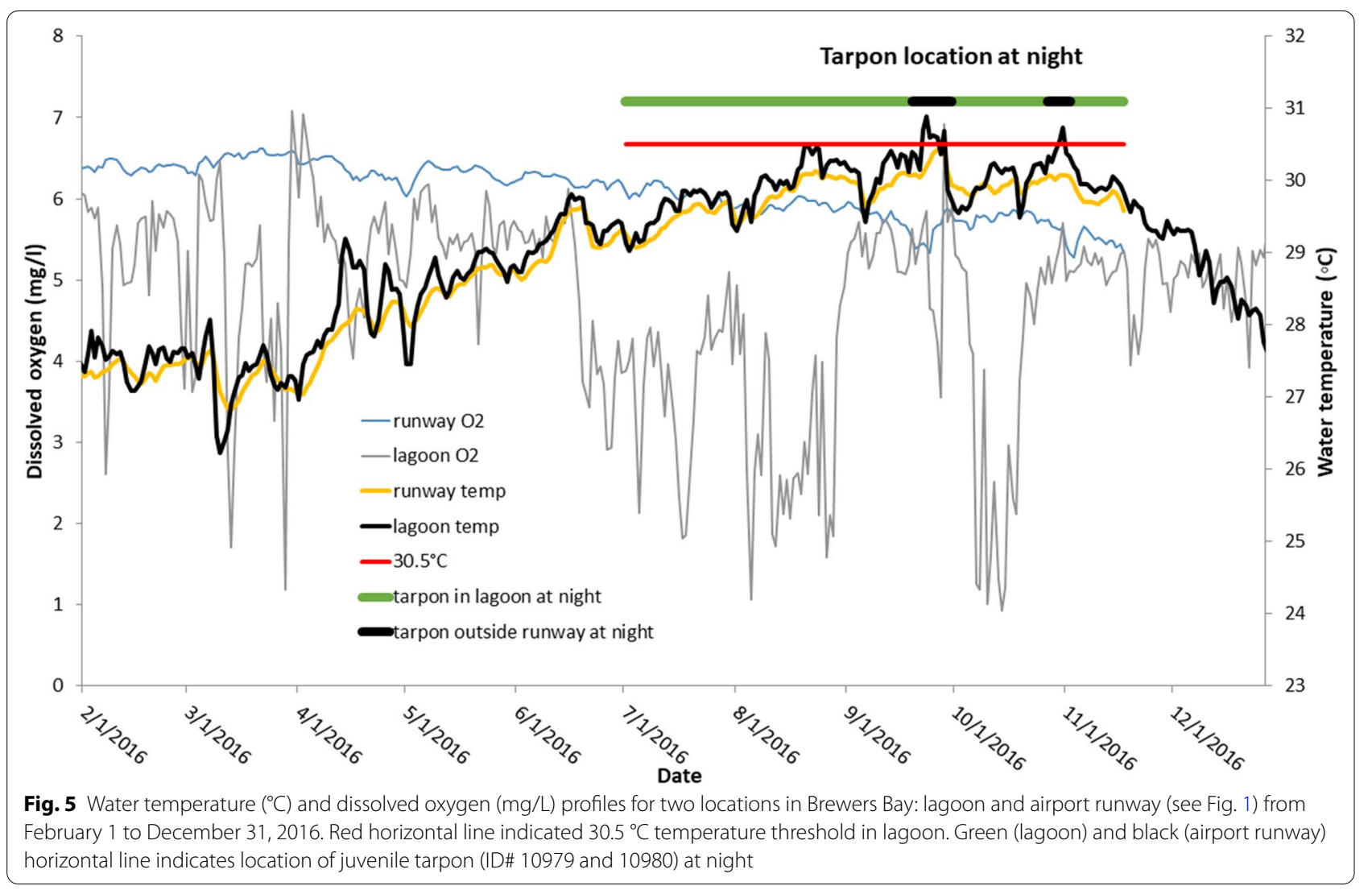

their activity space to similar areas within Brewers Bay. These changes in behavior and activity space coincided with the arrival of schools of bait fish as well as nesting seabirds that feed on these schools in the spring [43, 44]. When seabirds were present, we observed groups of tarpon foraging on bait fish near the surface during the spring months primarily in the middle of Brewers Bay and near Black Point reef (Duffing Romero, M. and Nemeth, R.S., pers. observations). This feeding strategy is not uncommon for tarpon and other pelagic predators, which can increase their foraging success in the presence of seabirds feeding on bait fish at the water surface $[15,43,45]$. The areas of Brewers Bay where this feeding behavior was observed corresponded to April daytime activity space of tagged tarpon.

Adult tarpon tend to feed at sunset and continue feeding into the night if there is enough food and available light for foraging $[15,46]$. As with other species [47], ROM was assessed as a proxy for feeding. Similar to adult tarpon, juveniles had the highest rates of movement during dawn and dusk, which suggests high feeding rates during crepuscular periods. However, this behavior may also indicate rapid movements along migration pathways between nighttime and daytime activity spaces $[18,48-54]$. ROM was significantly slower at night than other time periods, which suggests that juvenile tarpon were not feeding at this time. Further research with improved experimental design will help to distinguish differences between adult and juvenile behavioral states such as resting, foraging or traveling [55].

Juvenile tarpon generally stayed less than $10 \mathrm{~m}$ depth, but occasionally went to $25 \mathrm{~m}$ or deeper, which is also typical for adult tarpon [6, 13]. Many coastal and pelagic fish, such as barracuda (Sphyraena barracuda), white marlin (Kajikia albida), dolphinfish (Coryphaena. hippurus) and many species of tuna (Thunnus spp) show similar vertical movement patterns, where they spend the majority of time at shallow depths or close to the surface and then make diel/seasonal deep water movements [56-58]. Adult tarpon show a variety of vertical distributions that fall into four typical patterns: (1) clear diel pattern shallow in day and deep at night; (2) deep in day and shallow at night; (3) deep and shallow at irregular intervals throughout diel period, and (4) random vertical movements throughout diel period [6]. Juvenile tarpon in Brewers Bay showed a consistent diel vertical movement pattern that matched pattern (2) where fish stayed shallow at night and deeper during the day. At smaller sizes juvenile tarpon 


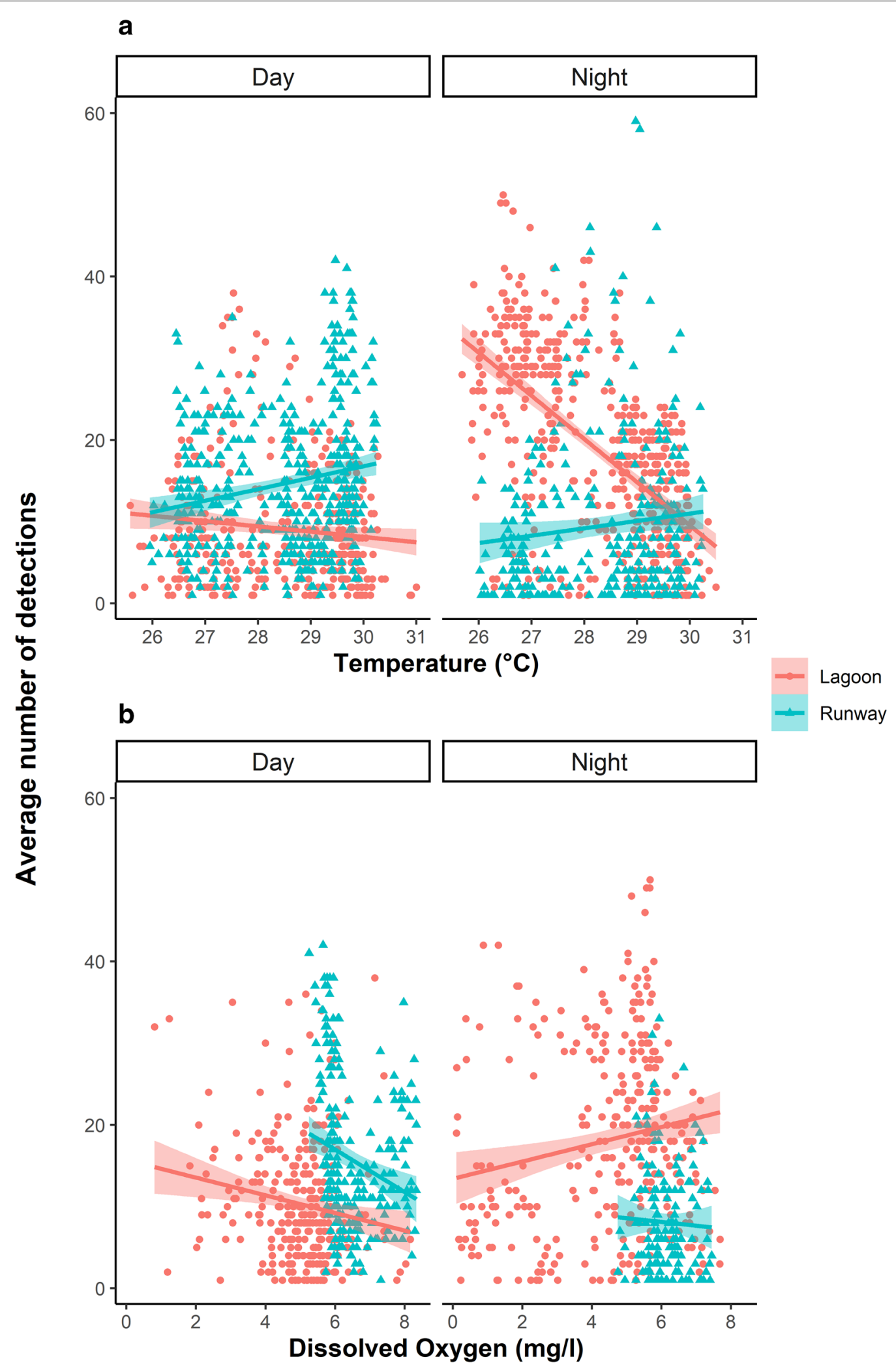

Fig. 6 Day and night relationships between average number of tarpon detections and $\mathbf{a}$ water temperature $\left({ }^{\circ} \mathrm{C}\right.$ ) and $\mathbf{b}$ dissolved oxygen (mg/L) within the lagoon and along the airport runway 
may select shallow, sheltered lagoon-type habitats, if available, as a strategy against predation $[14,15]$. In this study, all four tarpon used the Brewers Bay lagoon consistently throughout most of the year.

Environmental conditions influenced tarpon behavior in Brewers Bay. Tarpon prefer water temperatures from 24 to $26{ }^{\circ} \mathrm{C}$ in spring and fall and $28-30{ }^{\circ} \mathrm{C}$ in summer $[6,13,23]$. We found that juvenile tarpon avoided water temperatures greater than $30{ }^{\circ} \mathrm{C}$. For instance, tarpon detection frequencies within the lagoon decreased at temperatures above $29^{\circ} \mathrm{C}$ and they did not enter nor rest in the lagoon at night when water temperature was higher than $30.5{ }^{\circ} \mathrm{C}$, but instead moved to deeper water on the south side of airport runway (Fig. 5). At this threshold temperature, tarpon faced a trade-off of remaining in higher temperatures within the protected lagoon or leaving the lagoon for cooler, less protected waters around the airport runway at night. Previous studies on barracuda and bonefish (Albula vulpes) have shown that both species move to deeper waters away from their home range to avoid seasonal weather patterns and associated temperature fluctuations [15, 39, 59]. Adult tarpon in Florida migrated farther northward on a daily basis as sea surface temperatures increased and seemed to track the $26{ }^{\circ} \mathrm{C}$ isotherm from the Florida Keys to the southern coast of Virginia from May to July, respectively [6]. Despite the effect of high water temperatures on tarpon behavior, tarpon tolerated low dissolved oxygen concentrations in the lagoon, which is attributed to being facultative air-breathers $[13,60]$.

\section{Conclusion}

To our knowledge, this acoustic telemetry study provided some of the first information on juvenile tarpon movement ecology including home range size, rates of movement, vertical distribution, and habitat partitioning. Although limited to only four fish, our results showed high residency within a small bay and relatively stable non-overlapping daytime home ranges, except when seasonally abundant food sources were present. Fine-scale acoustic tracking over multiple years showed the effects of changing environmental conditions on juvenile tarpon movement and habitat use. These baseline observations highlight the need for more extensive studies of juvenile tarpon across a broader range of their distribution. In addition to a larger sample size, we suggest including a wider range of tarpon size classes, from small juveniles to large reproductive adults, in future studies. Since tarpon are highly mobile but also show resident behavior $[6,7$, $13,40]$, it is difficult to assess their larger-scale movement patterns using an acoustic array limited to one bay. A better approach, to facilitate tracking tarpon movements over a broader geographic range, would be to tag tarpon with both acoustic and satellite tags and place additional receivers along the coastlines or use a regional network within and among neighboring islands $[9,40,61,62]$.

\section{Abbreviations}

COA: Center of activity; MCP: Minimum convex polygon; KUD: Kernel utilization distribution; ROM: Rate of movement; HR: Home range.

\section{Supplementary Information}

The online version contains supplementary material available at https://doi. org/10.1186/s40317-021-00239-x.

Additional file 1: Table S1. Summary data for vertical distribution (m) of juvenile tarpon from box plot analysis.

\section{Acknowledgements}

We want to thank Damon Bo Green and Tyler S. Best for assisting in the field to catch and tag many of the tarpon in this study. We thank Jonathan Jossart for conducting detection range tests and assisting in the maintenance of the Brewers Bay acoustic array in the beginning of the project. We thank master's students in Marine and Environmental Studies who helped download acoustic receiver data in the field. We also want to thank the Center of Marine and Environmental Science at the University of the Virgin Islands for providing the facilities to complete this project. This is contribution \# 212 of the University of the Virgin Islands, Center for Marine and Environmental Studies.

\section{Authors' contributions}

MDDR conducted most of the field work, data analyses/interpretation and writing; JKM contributed to data management/analyses; RSN secured funding for project and contributed to field work; JL, SJP, JKM, JSA and RSN contributed to data interpretation and writing of manuscript. All authors read and approved the final manuscript.

\section{Funding}

Funding for this research was supported by VI-Established Program to Stimulate Competitive Research (VI-EPSCoR) through the NSF Grant \#1355437.

\section{Availability of data and materials}

The datasets used and/or analyzed during the current study are available from the corresponding author on reasonable request.

\section{Declarations}

Ethics approval and consent to participate

All capture and tagging methodology on all fish in Brewers Bay was approved by the University of the Virgin Islands Institutional Animal Care and Use Committee (IRB \#747807-1).

\section{Consent for publication}

Not applicable.

\section{Competing interests}

The authors declare that they have no competing interests.

\section{Author details \\ ${ }^{1}$ Center for Marine and Environmental Studies, University of the Virgin Islands, 2 John Brewers, US Virgin Islands, St. Thomas 00803, USA. ${ }^{2}$ Great Lakes Institute for Environmental Research, University of Windsor, 2990 Riverside Dr. W, Wind- sor, ON N9C 1A2, Canada. ${ }^{3}$ Department of Marine Ecosystems and Society, University of Miami, 4600 Rickenbacker Causeway, Miami, FL 33149, USA. ${ }^{4}$ Marine Conservation Research Group, School of Biological and Marine Sci- ences, Marine Building, University of Plymouth, Plymouth PL4 8AA, UK.}




\section{References}

1. Pittman SJ, McAlpine CA. Movements of marine fish and decapod crustaceans: process, theory and application. In: Advances in marine biology. Elsevier; 2003. pp. 205-94. https://doi.org/10.1016/S0065-2881(03) 44004-2.

2. Dingle $H$, Drake VA. What is migration? BioScience. 2007;57:113-21. Available from: http://academic.oup.com/bioscience/article/57/2/113/ 228325/What-Is-Migration. Accessed Oct 2015.

3. Liedvogel M, Chapman BB, Muheim R, Åkesson S. The behavioural ecology of animal movement: reflections upon potential synergies. Animal Migration. 2013;1. https://doi.org/10.2478/ami-2013-0002

4. Nathan R, Getz WM, Revilla E, Holyoak M, Kadmon R, Saltz D, et al. A movement ecology paradigm for unifying organismal movement research. Proc National Acad Sci. 2008;105:19052-9. https://doi.org/10. 1073/pnas.0800375105

5. Pittman SJ, Monaco ME, Friedlander AM, Legare B, Nemeth RS, Kendall MS, et al. Fish with chips: tracking reef fish movements to evaluate size and connectivity of caribbean marine protected areas. In: Fulton CJ, editor. PLoS ONE. 2014;9:e96028. https://doi.org/10.1371/journal.pone.00960 28.

6. Luo J, Ault J. Vertical movement rates and habitat use of Atlantic tarpon. Mar Ecol Prog Ser. 2012;467:167-80. https://doi.org/10.3354/meps09957.

7. Luo J, Ault JS, Ungar BT, Smith SG, Larkin MF, Davidson TN, et al. Migrations and movements of Atlantic tarpon revealed by two decades of satellite tagging. Fish Fish. 2020;21:290-318. https://doi.org/10.1111/faf. 12430.

8. Farmer N, Ault J. Grouper and snapper movements and habitat use in Dry Tortugas. Florida Mar Ecol Prog Ser. 2011;433:169-84. https://doi.org/10. 3354/meps09198.

9. Farmer NA, Ault JS. Modeling coral reef fish home range movements in dry tortugas, Florida. Sci World J. 2014;2014:1-14. https://doi.org/10.1155/ 2014/629791.

10. Knip DM, Heupel MR, Simpfendorfer CA. To roam or to home: site fidelity in a tropical coastal shark. Mar Biol. 2012;159:1647-57. https://doi.org/10. 1007/s00227-012-1950-5.

11. Biggs $C$, Nemeth R. Spatial and temporal movement patterns of two snapper species at a multi-species spawning aggregation. Mar Ecol Prog Ser. 2016;558:129-42. https://doi.org/10.3354/meps11846.

12. Kendall MS, Siceloff L, Winship A, Monaco ME. Determining conservation potential of an opportunistically defined MPA boundary using fish telemetry. Biol Cons. 2017;211:37-46. https://doi.org/10.1016/j.biocon.2017.05. 010.

13. Ault JS, editor. Biology and management of the world tarpon and bonefish fisheries. Boca Raton [Fla.] ; London: CRC Series on Marine Biology; 2008

14. Hammerschlag N, Luo J, Irschick DJ, Ault JS. A comparison of spatial and movement patterns between sympatric predators: bull sharks (Carcharhinus leucas) and Atlantic Tarpon (Megalops atlanticus). In: Stow A, editor. PLoS ONE. 2012;7:e45958. https://doi.org/10.1371/journal.pone.0045958.

15. Ault J, Humston R, Larkin M, Perusquia E, Farmer N, Luo J, et al. Population dynamics and resource ecology of Atlantic Tarpon and Bonefish. In: Biology and management of the world tarpon and bonefish fisheries. Boca Raton [Fla.]: CRC Series on Marine Biology; 2008. pp. 217-58.

16. Murchie KJ, Cooke SJ, Danylchuk AJ, Danylchuk SE, Goldberg TL, Suski CD, et al. Movement patterns of bonefish (Albula vulpes) in tidal creeks and coastal waters of Eleuthera. The Bahamas Fisheries Res. 2013;147:404-12. https://doi.org/10.1016/j.fishres.2013.03.019.

17. Montaño OJF. Assessing the habitat structure for common snook (Centropomus undecimalis Bloch, 1792) and tarpon (Megalops atlanticus Valenciennes, 1847) in Santa Teresa lagoons, Puerto Rico. Turk J Fish Aquat Sci. 2009;9:173-9. https://doi.org/10.4194/trjfas.2009.0208.

18. Matich P, Ault JS, Boucek RE, Bryan DR, Gastrich KR, Harvey CL, et al. Ecological niche partitioning within a large predator guild in a nutrientlimited estuary: Niche partitioning among estuarine predators. Limnol Oceanogr. 2017;62:934-53. https://doi.org/10.1002/Ino.10477.

19. Crabtree RE, Cyr EC, Chacón Chaverri D, McLarney WO, Dean JM. Reproduction of Tarpon, Megalops atlanticus, from Florida and Costa Rican Waters and Notes on their Age and Growth. Bull Mar Sci. University of Miami-Rosenstiel School of Marine and Atmospheric Science; 1997;61:271-85
20. Crabtree RE, Snodgrass D, Harnden C. Maturation and reproductive seasonality in bonefish, Albula vulpes, from the waters of the Florida Keys. Fishery Bulletin. 3:10. Available from: https://spo.nmfs.noaa.gov/content/ maturation-and-reproductive-seasonality-bonefish-albula-vulpes-watersflorida-keys. Accessed Mar 2016.

21. Baldwin J, Snodgrass D. Reproductive Biology of Atlantic tarpon Megalops atlanticus. In: Biology and management of the world Tarpon and Bonefish fisheries. Boca Raton [Fla.] ; London: CRC Series on Marine Biology; 2008. pp. 195-201.

22. Luo J, Ault J, Larkin M, Barbieri L. Salinity measurements from pop-up archival transmitting (PAT) tags and their application to geolocation estimation for Atlantic tarpon. Mar Ecol Prog Ser. 2008;357:101-9. https:// doi.org/10.3354/meps07288.

23. Luo J, Ault J, Larkin M, Humston R, Olson D. Seasonal migratory patterns and vertical habitat utilization of Atlantic Tarpon (Megalops atlanticus) from Satellite PAT Tags. In: Biology and management of the world tarpon and bonefish fisheries. 2008. pp. 275-99.

24. Kessel ST, Cooke SJ, Heupel MR, Hussey NE, Simpfendorfer CA, Vagle $\mathrm{S}$, et al. A review of detection range testing in aquatic passive acoustic telemetry studies. Rev Fish Biol Fisheries. 2014;24:199-218. https://doi. org/10.1007/s11160-013-9328-4.

25. Jossart, Jonathan. Mare Nostrum Range Testing Report. University of the Virgin Islands; 2015 p. 21.

26. Matley JK, Eanes S, Nemeth RS, Jobsis PD. Vulnerability of sea turtles and fishes in response to two catastrophic Caribbean hurricanes. Irma and Maria Sci Rep. 2019;9:14254. https://doi.org/10.1038/s41598-019-50523-3.

27. R Core Team. R: A lanaguage and environment for statistical computing. [Internet]. Vienna, Austria: R Foundation for Statistical Computing.; 2017. Available from: http://www.R-project.org/. Accessed Jan 2016.

28. US Naval Observatory. Sun or moon rise/set table for one year [Internet]. 2016 [cited 2018 Jan 15]. Available from: http://aa.usno.navy.mil/data/ docs/RS_OneYear.php. Accessed Jan 2018.

29. Simpfendorfer CA, Heupel MR, Hueter RE. Estimation of short-term centers of activity from an array of omnidirectional hydrophones and its use in studying animal movements. Can J Fish Aquat Sci. 2002;59:23-32. https://doi.org/10.1139/f01-191.

30. Calenge $\mathrm{C}$. The package "adehabitat" for the R software : a tool for the analysis of space and habitat use by animal 2006

31. Kranstauber B, Smolla M, Scharf AK. move: Visualizing and Analyzing Animal Track Data [Internet]. 2017. Available from: https://CRAN.R-project. org $/$ package=move. Accessed Jan 2018.

32. Heupel MR, Simpfendorfer CA, Hueter RE. Estimation of Shark Home Ranges using Passive Monitoring Techniques. Environ Biol Fishes. 2004;71:135-42. https://doi.org/10.1023/B:EBFI.0000045710.18997.f7.

33. Yeiser BG, Heupel MR, Simpfendorfer CA. Occurrence, home range and movement patterns of juvenile bull (Carcharhinus leucas) and lemon (Negaprion brevirostris) sharks within a Florida estuary. Mar Freshwater Res. 2008;59:489. https://doi.org/10.1071/MF07181.

34. Bivand R, Rundel C, Pebesma E, Stuetz R, Hufthammer KO, Giraudoux P, et al. rgeos: interface to Geometry Engine-Open Source ('GEOS') [Internet]. 2019. Available from: https://CRAN.R-project.org/package=rgeos. Accessed Mar 2019

35. Kernohan BJ, Gitzen RA, Millspaugh JJ. Chapter 5-Analysis of animal space use and movements. In: Millspaugh JJ, Marzluff JM, editors. Radio tracking and animal populations [Internet]. San Diego: Academic Press; 2001. p. 125-66. Available from: http://www.sciencedirect.com/science/ article/pii/B9780124977815500062. Accessed Mar 2019.

36. Walter WD, Fisher, J.W. Manual of Applied Spatial Ecology [Internet]. Pennsylvania State University; 2016. Available from: http://ecosystems. psu.edu/research/labs/walter-lab. Accessed Jun 2017.

37. Fox J, Weisberg S. An R companion to applied regression. Thousand Oaks: Second. Sage; 2011

38. Pinheiro J, Bates D, DebRoy SS, Sarkar D. NIme: linear and nonlinear mixed effects models [Internet]. 2018. Available from: https://cran.r-project.org/ package $=$ nlme. Accessed Mar 2018

39. O'Toole AC, Danylchuk AJ, Goldberg TL, Suski CD, Philipp DP, Brooks E, et al. Spatial ecology and residency patterns of adult great barracuda (Sphyraena barracuda) in coastal waters of The Bahamas. Mar Biol. 2011;158:2227-37. https://doi.org/10.1007/s00227-011-1728-1. 
40. Griffin LP, Brownscombe JW, Adams AJ, Boucek RE, Finn JT, Heithaus MR, et al. Keeping up with the Silver King: Using cooperative acoustic telem etry networks to quantify the movements of Atlantic tarpon (Megalops atlanticus) in the coastal waters of the southeastern United States. Fish Res. 2018;205:65-76. https://doi.org/10.1016/j.fishres.2018.04.008.

41. Ault J. Silver King — a most perfect and ancient sportfish: the biology, ecology and management of Megalops atlanticus - and its precarious future. A passion for tarpon. Mill Creek, WA: Wild River Press; 2010. pp. 261-86.

42. Viñola Valadez, L, Cotayo Cedeño, L, Zurcher, N. coastal ecosystem management to support bonefish and Tarpon Sportfishing in Peninsula de Zapata National Park, Cuba. In: Biology and management of the world tarpon and bonefish fisheries. Boca Raton [Fla.] ; London: CRC Series on Marine Biology; 2008. pp. 93-8.

43. Shealer D. Foraging behavior and food of seabirds. In: Biology of marine birds. Boca Raton [Fla.] ; London; 2001. pp. 137-78.

44. Soanes LM, Bright JA, Carter D, Dias MP, Fleming T, Gumbs K, et al. Important foraging areas of seabirds from Anguilla, Caribbean: implications for marine spatial planning. Mar Policy. 2016;70:85-92. https://doi.org/10. 1016/j.marpol.2016.04.019.

45. Silvano R. Feeding habits and interspecific feeding associations of Caranx Latus (Carangidae) in a subtropical reef. Environ Biol Fishes. 2001;60:46570. https://doi.org/10.1023/A:1011064923544.

46. Kopperud K, Grace M. Circadian rhythms of retinal sensitivity in the Atlantic tarpon, Megalops atlanticus. Bull Mar Sci. 2017;93:285-300. https://doi. org/10.5343/bms.2016.1045.

47. Cartamil DP, Vaudo JJ, Lowe CG, Wetherbee BM, Holland KN. Diel movement patterns of the Hawaiian stingray, Dasyatis lata: implications for ecological interactions between sympatric elasmobranch species. Mar Biol. 2003;142:841-7. https://doi.org/10.1007/s00227-003-1014-y.

48. Nagelkerken I, Dorenbosch M, Verberk W, Cocheret de la Morinière E, van der Velde G. Day-night shifts of fishes between shallow-water biotopes of a Caribbean bay, with emphasis on the nocturnal feeding of Haemulidae and Lutjanidae. Mar Ecol Prog Ser. 2000;194:55-64. https://doi.org/10. 3354/meps 194055 .

49. Meyer CG, Papastamatiou YP, Holland KN. Seasonal, diel, and tidal movements of green jobfish (Aprion virescens, Lutjanidae) at remote Hawaiian atolls: implications for marine protected area design. Mar Biol. 2007;151:2133-43. https://doi.org/10.1007/s00227-007-0647-7.

50. Meyer C, Holland K, Papastamatiou Y. Seasonal and diel movements of giant trevally Caranx ignobilis at remote Hawaiian atolls: implications for the design of marine protected areas. Mar Ecol Prog Ser. 2007;333:13-25. https://doi.org/10.3354/meps333013.

51. Afonso P, Fontes J, Holland K, Santos R. Multi-scale patterns of habitat use in a highly mobile reef fish, the white trevally Pseudocaranx dentex, and their implications for marine reserve design. Mar Ecol Prog Ser. 2009;381:273-86. https://doi.org/10.3354/meps07946.

52. Luo J, Serafy J, Sponaugle S, Teare P, Kieckbusch D. Movement of gray snapper Lutjanus griseus among subtropical seagrass, mangrove, and coral reef habitats. Mar Ecol Prog Ser. 2009;380:255-69. https://doi.org/10. 3354/meps07911.

53. Hitt S, Pittman SJ, Brown KA. Tracking and mapping sun-synchronous migrations and diel space use patterns of Haemulon sciurus and Lutjanus apodus in the U.S. Virgin Islands. Environ Biol Fish. 2011;92:525-38. https:// doi.org/10.1007/s10641-011-9875-2.

54. Topping DT, Szedlmayer ST. Home range and movement patterns of red snapper (Lutjanus campechanus) on artificial reefs. Fish Res. 2011;112:7784. https://doi.org/10.1016/j.fishres.2011.08.013.

55. Hamer KC, Humphreys EM, Magalhães MC, Garthe S, Hennicke J, Peters G, et al. Fine-scale foraging behaviour of a medium-ranging marine predator. J Anim Ecol. 2009;78:880-9. https://doi.org/10.1111/j.1365-2656.2009. 01549.x.

56. Hansen NR, Kerstetter DW. Habitat utilization and vertical distribution of the Great Barracuda Sphyraena barracuda (Edwards 1771) in the western North Atlantic using electronic archival tags. GCR. 2015; SC4-SC9. https:// doi.org/10.18785/gcr.2601.06

57. Hoolihan JP, Luo J, Snodgrass D, Orbesen ES, Barse AM, Prince ED. Vertical and horizontal habitat use by white marlin Kajikia albida (Poey, 1860) in the western North Atlantic Ocean. ICES J Mar Sci. 2015;72:2364-73. https://doi.org/10.1093/icesjms/fsv082.

58. Whitney NM, Taquet M, Brill RW, Girard C, Schwieterman GD, Dagorn L, et al. Swimming depth of dolphinfish (Coryphaena hippurus) associated and unassociated with fish aggregating devices. FB. 2016;114:426-34. https://doi.org/10.7755/FB.114.4.5.

59. Danylchuk AJ, Cooke SJ, Goldberg TL, Suski CD, Murchie KJ, Danylchuk SE, et al. Aggregations and offshore movements as indicators of spawning activity of bonefish (Albula vulpes) in The Bahamas. Mar Biol. 2011;158:1981-99. https://doi.org/10.1007/s00227-011-1707-6.

60. Geiger S, Torres J, Crabtree R. Air breathing and gill ventilation frequencies in juvenile Tarpon, Megalops atlanticus: responses to changes in dissolved oxygen, temperature, hydrogen sulfide, and PH. Environ Biol Fishes. 2000;59:181-90. https://doi.org/10.1023/A:1007640132059.

61. Hussey NE, Kessel ST, Aarestrup K, Cooke SJ, Cowley PD, Fisk AT, et al. Aquatic animal telemetry: a panoramic window into the underwater world. Science. 2015;348:1255642-1255642. https://doi.org/10.1126/ science. 1255642.

62. Currier R, Kirkpatrick B, Simoniello C, Lowerre-Barbieri S, Bickford J. iTAG: Developing a cloud based, collaborative animal tracking network in the Gulf of Mexico. OCEANS 2015-MTS/IEEE Washington. Washington, DC: IEEE; 2015. pp. 1-3. http://ieeexplore.ieee.org/document/7401864/. Accessed Sept 2019.

\section{Publisher's Note}

Springer Nature remains neutral with regard to jurisdictional claims in published maps and institutional affiliations.

Ready to submit your research? Choose BMC and benefit from:

- fast, convenient online submission

- thorough peer review by experienced researchers in your field

- rapid publication on acceptance

- support for research data, including large and complex data types

- gold Open Access which fosters wider collaboration and increased citations

- maximum visibility for your research: over 100M website views per year

At BMC, research is always in progress.

Learn more biomedcentral.com/submissions 